QUADERNS DE FILOSOFIA VOL. VIII NÚM. 2 (202 I): 43-64

eISSN: $234 \mathrm{I}-3042$ DOI: I O.7203/QFIA. 8.2.I 8208

José Francisco Gómez Rincón ${ }^{1}$

Universitat de València

\title{
La fi de l'hegemonia neoliberal i el renaixement populista. L'antropologia neoliberal com a origen de l'actual moment populista
}

The end of neoliberal hegemony and the populist renaissance.

Neoliberal anthropology as the origin of the current populist moment

Rebut: 14/9/2020. Acceptat: 14/9/2021

Resum: A què es deu l'actual ressorgiment dels discursos populistes arreu del món? Aquesta és la pregunta que pretenem respondre en aquest article. Si avui vivim un "moment populista" és perquè la fallida del relat neoliberal ha obert una escletxa entre les expectatives dels individus i les veritables possibilitats d'un món finit on els recursos per satisfer una societat obsessionada amb la satisfacció de desitjos superflus és insostenible, des del punt de vista tant polític com econòmic. La crisi econòmica de l'any 2008 ha deixat orfes uns subjectes que, a causa d'un profund treball de formació de la subjectivitat de marcada arrel neoliberal, són incapaços de renunciar a un estil de vida insostenible i que, com a conseqüència, recorren a les promeses d'uns partits que s'aprofiten de les circumstancies creades per aquestes condicions post-Gran Recessió per guanyar poder.

Abstract: What is the reason for the current resurgence of populist discourses around the world? This is the question that we intend to answer in this article. If

${ }^{1}$ Doctorand del programa Ètica i Democràcia de la Universitat de València.

Vaig començar a redactar el present article durant l'estada d'investigació que vaig realitzar al Centro de Estudios Políticos y Constitucionales de Madrid, que va durar de l'1 de març al 31 de maig de l'any 2020. M'agradaria deixar constància ací del meu agraïment a aquest centre per haver pogut gaudir de l'experiència, tot i les dificultats que va ocasionar la pandèmia de la Covid-19 durant aquell temps. 
nowadays we live a "populist moment" is because the failure of the neoliberal narrative has opened a gap between the individuals' expectations and the true possibilities of a finite world where resources to satisfying a society obsessed with the satisfaction of superfluous desires is unsustainable both politically and economically. The economic crisis of 2008 has orphaned some subjects who, due to a deep work of formation of subjectivity with a marked neoliberal root, are unable to give up an unsustainable lifestyle, and who, as a result, resort to promises of parties that take advantage of the circumstances created by these post-Great Recession conditions, in order to gain power.

Paraules clau: hegemonia, bloc històric, significant vuit, neoliberalisme, populisme, neuropolítica.

Keywords: hegemony, historical bloc, meaning eight, neoliberalism, populism, neuropolitics.

\section{INTRODUCCIÓ}

E L'ACTUALITAT vivim un fort ressorgiment dels discursos populistes. Tant des de l'esquerra política com des de la dreta cada cop són més els partits que empren d'aquest tipus de discursos per tal de convèncer l'electorat de votar per una formació política o un altra. Les democràcies d'Europa i d'Amèrica veuen créixer els anomenats partits populistes i molts d'ells arriben a assolir el poder executiu dels Estats per mitjà del triomf electoral. El cas del president Donald Trump als Estat Units d'Amèrica o de Jair Bolsonaro al Brasil són exemples d'això mateix. Mentrestant, al vell continent, partits com el Front Nacional francès o Unidas Podemos a Espanya, que empren amb regularitat el discurs populista, veuen créixer les seves possibilitats d'assolir posicions de poder en cadascuna de les respectives enquestes electorals publicades. Així, en aquesta dècada que vivim, sembla que el fantasma que recorre Europa és el del populisme.

A què es deu aquest ressorgiment amb tanta força dels discursos populistes? Aquesta és la pregunta que pretenem respondre en aquest article. I és que si avui dia vivim un "moment populista" arreu del món és perquè la fallida del relat neoliberal ha obert una escletxa entre les expectatives dels individus i les veritables possibilitats d'un món finit on els recursos per satisfer una societat obsessionada amb la satisfacció de desitjos superflus és insostenible, tant des del punt de vista polític com econòmic. La crisi econòmica de l'any 2008 ha deixat orfes uns subjectes que, a causa d'un profund treball de formació de la subjectivitat de marcada arrel neoliberal, són incapaços de renunciar a un estil de vida insostenible i 
que, com a conseqüència, recorren a les promeses d'uns partits que s'aprofiten de les circumstancies creades per aquestes condicions post-Gran Recessió.

Però, què implica dir que vivim un "moment populista" en l'actualitat? Amb aquestes paraules la teòrica de la política Chantal Mouffe es refereix a un moment determinat en què forces polítiques contràries a un consens establert sobre com han de ser les coses tenen possibilitats d'assolir el poder emprant una estratègia electoral de caire populista (LACLAU 2008, 9-15). Un moment populista seria, doncs, l'equivalent polític a un canvi de paradigma en termes de Thomas Kuhn i la seva concepció d'una revolució científica: un moment on el sentit comú canvia. Aquest canvi del sentit comú polític té unes causes determinades que Mouffe explica per mitjà d'una visió de la política que es remunta als plantejaments teòrics sobre el canvi polític d'Antonio Gramsci i els continuadors del seu treball en l'actualitat com són el ja difunt Ernesto Laclau i la mateixa Mouffe.

Així doncs, per entendre què és el que implica viure un moment populista cal entendre què vol dir el terme "sentit comú" des del punt de vista d'aquests pensadors. En una situació normal, una que no és un "moment populista", hi ha una sèrie de consensos establerts sobre el significat de certs conceptes fonamentals. Termes com "llibertat" o "igualtat" prenen significats en funció d'una relació de forces determinada en un moment molt concret de la història d'una societat política (GramsCI 20I7, 201-2). Termes com aquests són, segons els va caracteritzar Ernesto Laclau, "significants buits", ja que el seu significat no és fixe sinó que canvia segons que convé en cada circumstància (LAClaU 2008, 163-74). La capacitat de definir el significat d'aquests conceptes implica ostentar una posició d' "hegemonia" per part d'una força política concreta (LAClau i Moufre 2015, 177-91); així, que el concepte de "llibertat" s'entengui com una situació d'absència de coacció o una de no dominació per part de la ciutadania depèn de quina sigui la força política que ostenti l'hegemonia en eixe moment particular. Aquests conceptes, aquests significants buits, són la clau per aconseguir el poder, segons Laclau. Qui pugui definir-los segons les seves conveniències polítiques serà qui guanyi les confrontacions polítiques, ja sigui en unes eleccions o en una revolució violenta (LaCLAu i Mouffe 20I 5, 170-7). D'altra banda, aquesta hegemonia cultural crea un "sentit comú", uns marcs de pensament sobre com han de ser les coses al món; una racionalitat per la qual els subjectes interpreten la realitat i classifiquen els comportaments de les persones en unes situacions concretes.

La tesis que aparece en la introducción a la Crítica de la economía política acerca de que los hombres toman conciencia de los conflictos estructurales en el terreno de las ideas debe ser entendida como una afirmación gnoseológica y no 
psicológica y moral. De ahí se sigue que el principio teórico-práctico de la hegemonía tiene también un sentido gnoseológico. [...] La realización de un aparato hegemónico, en la medida en que crea un nuevo terreno ideológico, determina una reforma de la conciencia y de los métodos de conocimiento, es un hecho de conocimiento, un hecho filosófico. En términos croceanos: cuando se logra introducir una nueva moral conforme a una nueva concepción del mundo, se acaba por introducir también esa concepción, es decir, se produce una reforma filosófica completa (Gramsci 2017, 202)

Normalment els significants buits es troben ben definits, pel fet que una ideologia, un sistema polític concret, ostenta l'hegemonia de forma clara. Aquesta circumstancia configura un "bloc històric", estableix un sentit comú: "se sigue que solo un sistema total de ideologías refleja racionalmente las contradicciones de la estructura y representa la existencia de condiciones objetivas para la transformación de la praxis" (GrAMSCI 20I7, 203). Quan això canvia, quan la ideologia hegemònica deixa de ser capaç de definir a conveniència el que volen dir els significants buits, el bloc històric decau i això permet un escenari de canvi de paradigma, és a dir, la possibilitat de redefinir aquests significants buit per part d'altres forces, que aleshores esdevindran hegemòniques (Laclau i Mouffe 20 I 5, 177-91). Simplement, en aquestes circumstancies, el que s'interpretava com a sentit comú deixa d'estar clar i això obre la porta a les possibilitats d'un canvi de paradigma. Aquest és el moment populista on el que hi ha en joc és la possibilitat de canviar el món: de crear un nou bloc històric, un nou sentit comú com a conseqüència d'una nova hegemonia cultural (Errejón i Mouffe 2oi 6, 32-5). De manera similar, Gramsci entenia que, si la revolució comunista volia triomfar a l'Europa occidental del seu temps, calia que els partits comunistes lluitaren per tal de fer-se amb l'hegemonia cultural, que fins aleshores ostentaven els partits burgesos (guerra de posicions), perquè si no, si intentaven una revolució violenta (atac frontal o guerra de moviments), serien derrotats en tant que els Estats burgesos posseeixen el monopoli de la força. La conquesta de l'hegemonia tindria com a objectiu deixar indefens l'Estat burgés en convertir policies i soldats a la ideologia comunista, la qual cosa equivaldria a la victòria final. ${ }^{2}$

${ }^{2}$ En aquesta manera d'entendre la política com una lluita per l'hegemonia es basen Laclau i Mouffe per a explicar com, en un context neoliberal, pot l'esquerra política no adscrita a aquest corrent ideològic disputar el poder per mitjà de la utilització del discurs populista (LACLAU i Mouffe 2015, 11-24). Així, en un primer moment aquesta manera d'entendre la situació del "moment populista" seria útil sols per als partits d'esquerres, però creiem que aquest aparell teòric desenvolupat per Mouffe i Laclau, basat en la relectura que elaboren dels textos gramscians, es pot aplicar també a tota forma de populisme, sigui d'esquerres o dretes, perquè la situació política de trencament del marc hegemònic és la mateixa per a tots els actors polítics que s'hi 
Se ha entrado en una fase culminante de la situación político-histórica, porque en la política la "guerra de posición" una vez conseguida la victoria en ella, es definitivamente decisiva. $\mathrm{O}$ sea: en política se tiene guerra de movimientos mientras se trata de conquistar posiciones no decisivas y, por tanto, no se movilizan todos los recursos de la hegemonía del Estado; pero cuando, por una u otra razón, estas posiciones han perdido todo valor y solo importan las posiciones decisivas, entonces se pasa a la guerra de posición (GramsCi 20I7, 246-7)

Si en l'actualitat vivim un moment populista és perquè assistim a un d'aquests moments extraordinaris de trencament del bloc històric on l'hegemonia està en joc i les forces polítiques - els partits - empren del discurs populista per tal de dotar d'un significat particular i convenient per a ells aquests conceptes clau que són els "significants buits". Aquest moment populista actual és, doncs, fruit del trencament d'una sèrie de consensos previs, d'una forma determinada d'entendre el món. Si en els temps que corren vivim un moment populista és perquè el temps d'hegemonia del sistema neoliberal s'ha acabat i això obre el camí a les iniciatives polítiques i ideològiques alternatives a aquest sistema que ha quedat obsolet (CAstells 20I7, 11-5). El que hi ha, doncs, darrere del moment populista actual és la fi del relat neoliberal sobre el món i de les seves possibilitats.

\section{Hegemonia NEOliberal: la FORMACió NEUROPOlítica DE L'HOMO OECONOMICUS}

La fallida del relat neoliberal, que ha donat lloc a l'actual moment populista, és la conseqüència de la contradicció que existeix entre les possibilitats del món i el prototip humà que el neoliberalisme ha creat per tal de garantir la continuïtat del sistema econòmic capitalista de lliure mercat. Aquesta contradicció esclatà rere la crisi econòmica del 2008 quan el desplomament dels mercats financers va fer caure el llençol econòmic que encobria la bombolla especulativa sobre la qual se sustentava el mode de vida del ciutadà neoliberal.

L'actual manera de ser de les persones - el prototip antropològic dominant avui- és el resultat d'un procés d'exercici de poder sobre les persones per part del dispositiu de poder que és el neoliberalisme i que té els seus orígens en la dècada dels anys 80 del segle xx, quan es va produir l'anomenada "revolució

veuen involucrats i qualsevol ideologia pot emprar una estratègia populista per tal de fer-se amb l'hegemonia. Per tant, defensem que, tot i partir des de posicions d'esquerres, les aportacions teòriques d'aquest autors són també aplicables a la resta de forces polítiques amb independència de la seva ideologia. 
neoconservadora" que portà al poder a dirigents de marcat caire neoliberal respecte a la perspectiva econòmica i social. Margaret Thatcher al Regne Unit o Ronald Reagan als EUA són exemple d'aquest tipus de dirigents. L'objectiu però dels ideòlegs i artífex de la revolució neoconservadora d'aquell moment no era sols una conquesta temporal del poder per a aquests dirigents, sinó que el que pretenien era tota una nova manera de regir el comportament humà per tal de garantir-se, no ja el poder polític, sinó una hegemonia cultural que assegurés el manteniment d'un capitalisme exacerbat, el qual permetés la perpetuació d'un status quo mundial molt concret on el procés de la globalització, que aleshores començava a caminar, serveixi als interessos d'unes poques persones (Hardt i Negri 2005, 21-43).

L'objectiu dels artífex d'aquesta revolució conservadora era, doncs, mantenir uns nivells de guanys econòmics desmesurats per a una petita part de la població mundial, mentre que la gran majoria veuria empitjorar les seves vides, en entendre que el període socialdemòcrata anterior a aquella revolució conservadora havia suposat una democratització excessiva de les societats, donant massa poder a les majories socials, i que això era dolent per als interessos del gran empresariat mundial. ${ }^{3}$ En aquest sentit, el neoliberalisme el que pretén, des del mateix moment del seu naixement, és el control de les persones amb un objectiu molt concret: mantenir un capitalisme exacerbat, la qual cosa requereix d'un subjecte humà específic: l'homo oeconomicus (HARDT i NeGri 2005, 43-63). Amb tot, si bé la definició de l'esser humà com a homo oeconomicus no és un constructe teòric de la ideologia neoliberal — ja que aquesta definició comença a aparèixer al segle xviI de la mà d'autors com Thomas Hobbes o Jeremy

\footnotetext{
${ }^{3}$ En 1975 es va reunir l'anomenada "Comissió Trilateral" la qual va elaborar l'informe The crisis of democracy, per part de Samuel P. Huntington, Michael Crozier i Joji Watanuki, que defensaven que la crisi que per aquell moment travessaven les democràcies occidentals era el resultat d'un excés de participació política per part de la ciutadania i la excessiva influència de sindicats i d'altres organitzacions socials en la direcció de les polítiques dels Estats. És a dir, aquesta Comissió Trilateral argüia que, era l'excés de democràcia el que estava amenaçant la pròpia democràcia i per tal de posar remei a la situació, el que calia era disminuir la influència dels sindicats i organitzacions obreres sobre els governs (LAVAL i Dardot 20 i 5, 195). Aquestes conclusions de l'informe de la Trilateral foren d'una enorme influència per al pensament neocorservador, que defensava exactament el mateix: una disminució del poder polític de les organitzacions socials, especialment les d'esquerres, que alimentaven les exigències d'autodeterminació de les masses, acabant així amb el principi d'autoritat dels líders polítics i socials pertanyents a l'elit governant i sembrant així el caos i la confusió en les societats democràtiques. Per tant, com a corol-lari del plantejament, el que caldria per corregir la situació seria una tornada als valors tradicionals de les societats capitalistes, la família tradicional i la religió. Aquestes propostes incloïen també la limitació de les atribucions socials de l'Estat del benestar per tal de restar poder de negociació i força política a aquestes mateixes organitzacions sindicals. En definitiva, els neoconservadors prompte s'adheriren als plantejaments socials i polítics defensats pel neoliberalisme (CORTINA, 20 I I: 131).
} 
Bentham-, és el neoliberalisme de Friedrich Hayek el que al segle xx reprèn aquesta definició de l'esser humà com a prototip antropològic i assumeix que és la forma adient de ser humà si el que és pretén és el progrés de la civilització (Vergara Estévez 2009).

L'homo oeconomicus com a model antropològic és refereix a un subjecte que es caracteritza per un pretès egoisme racional, la qual cosa implica que l'homo oeconomicus sols es preocupa per ell mateix i la satisfacció dels seus interessos particulars, deixant de costat tot allò que no li reporti un guany immediat, ja sigui econòmic, polític o de qualsevol tipus, incloent plaers i relacions personals (VillacaÑas 2020, 146-65). Així doncs, parlem d'un subjecte que es defineix pel seu marcat egoisme psicològic, és a dir, un model d'esser humà construït sobre la idea que les persones són naturalment vicioses i desencarnades, l'objectiu únic de les quals a la vida és la satisfacció dels seus impulsos egoistes (Lemm 20 Io, 21-49). En aquest sentit, l'homo oeconomicus és el prototip humà perfecte per al sistema capitalista perquè aquest sistema econòmic requereix de persones amb una mentalitat propícia per al consum de bens i serveis que pugui proporcionar el sistema de lliure mercat. L'egoista racional és fonamental per al capitalisme perquè és el subjecte humà que troba satisfacció personal en el consumisme i l'adquisició dels productes per mitjà de l'intercanvi mercantil típic del capitalisme i que, per tant, és fonamental per al manteniment d'aquest mateix sistema econòmic (Foucault 2009, 187-213).

Ocorre, però, que aquest model antropològic no és natural. L'esser humà no és sols un egoista racional; té moltes altres cares, a voltes oposades a aquesta ultima. Per això el modern capitalisme requereix del neoliberalisme, perquè aquesta "ideologia" s'encarrega de produir aquesta mentalitat, reforçant la vessant consumista de l'homo oeconomicus en els subjectes a costa d'altres maneres de ser $\mathrm{i}$ inclinacions que hi ha en les persones. En aquest sentit el neoliberalisme és un dispositiu de poder que tracta de crear un prototip humà determinat i, per fer això, recorre a tota una sèrie d'estratègies de governamentabilitat que li permeten, per mitjà del control i la manipulació de les emocions, donar lloc a

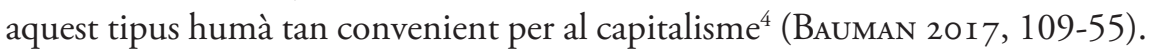

${ }^{4}$ Segons Hayek les persones no són egoistes racionals per natura, sinó que aprenen a ser-ho fruit de l'emulació del comportament d'aquells que tenen èxit, o de la percepció d'això mateix. $\mathrm{Si} \mathrm{la} \mathrm{cultura} \mathrm{dominant,} \mathrm{la} \mathrm{publicitat} \mathrm{i} \mathrm{tot} \mathrm{l'entorn} \mathrm{que} \mathrm{envolten} \mathrm{al} \mathrm{subjecte} \mathrm{llancen} \mathrm{sobre} \mathrm{aquest} \mathrm{la}$ idea que per tenir èxit en les seves empreses vitals particulars cal que es comporti com un egoista racional, això és el que farà aquest subjecte particular (VERGARA EsTÉVEZ 2009). D'aquesta manera, Hayek, sembla reconèixer que és la pressió social i de l'entorn la responsable del comportament del subjecte com un homo oeconomicus i que aquesta, novament, no és la forma natural de ser de les persones (HAYEK I998, 121-38). L'aparell de poder neoliberal actual actuaria per tal de configurar l'entorn en què viu el subjecte de mode tal que forcés a aquest per comportar-se com un egoista racional, oblidant, o tractant de fer oblidar, els altres trets característics dels essers humans, com la solidaritat desinteressada o la generositat amb el desafortunat (Lemm 20 Io, 177-97). 
La producció neoliberal de l'homo oeconomicus es dona per mitjà del control del subjecte a un nivell neurològic. El que es busca és que l'individu entenguí el món des d'uns paràmetres convenients per al sistema capitalista, de tal mode que el comportament de les persones està mediat per interpretacions del món prefixades per l'aparell de poder neoliberal (Laval i Dardot 201 5, 332-7). Funciona aquest condicionament per mitjà de l'establiment de codis de conducta que fixen el que ha de ser considerat com un comportament "normal" per a una persona sana. Aquesta manera correcta, "normal", de comportar-se és el de l'homo oeconomicus, i alhora qui es comporta d'una manera contrària a aquests codis de conducta "normals", qui no entra sota el patró de comportament de l'egoista racional, és considerat "anormal": un comportament patològic que ha de ser corregit amb mitjans clínics o reeducatius (FouCAULT 2009, 263-85). Aquests patrons de conducta s'inculquen en el subjecte des de moments molt primaris del desenvolupament de la personalitat i es basen en tècniques educatives destinades a configurar d'una manera concreta les connexions sinàptiques de les neurones, la qual cosa permet controlar el comportament humà a través de la configuració dels processos de pensament i d'interpretació del món. Així, el neoliberalisme tracta d'educar els subjectes en un sentit comú convenient per als seus interessos polítics i socials (HARDT i NEGRI 2005, 43-63).

Segons les conclusions que la investigació neurocientífica ha llançat sobre el procés de formació dels nostres pensaments, les impressions i afectes que el món exterior causen sobre nosaltres, així com la manera de respondre a aquestes, tenen una importància cabdal (ARIAs Maldonado 20I6, 81-93). Biologia i cultura es barregen per crear i configurar les diferents estructures cerebrals que permeten a les persones pensar i processar informació (ARIAS MALDONADO 2016, 53-71). Els éssers humans pensem i entenem el món exterior a través de marcs conceptuals, fruit del procés civilitzador i els contextos culturals en què ens movem i ens desenvolupem com a subjectes independents (ARIAS MALDONADO 20 I 6, 93-103). En altres paraules, pensem a través de "prejudicis" culturals, mitjançant metarelats que donen sentit a un món confús i desorganitzat. Són els prejudicis, les nostres idees preconcebudes culturalment sobre com són les coses, el que ens permet posar ordre en el caos (Conill i 991, 11-9).

Així, sí el món amb què ens les veiem és, en realitat, fruit de la cultura, fruit de les nostres creences, doncs aquestes creences configuren la nostra manera de pensar i de sentir, aquest mateix món exterior tal i com va sostenir, entre d'altres, José Ortega y Gasset (Ortega y Gasset 2007, 43-7 ). Les impressions que l'exterior produeix en nosaltres són fruit d'una resposta cultural (Arias Maldonado 20i6, 47-53). La calor que sentim quan acostem la mà al foc, és, sens dubte, una cosa biològica, però el sentiment que tenim d'aquesta 
sensació, el valor que donem a la calor, el que ens fa sentir emocionalment, és fruit de la cultura en què ens hem socialitzat i que ens defineix com a subjectes que pertanyen a una comunitat particular (Arias Maldonado 20i6, 81-93).

Les emocions són, per tant, producte de tot un seguit de mediacions culturals, sentir alguna cosa no és més que dotar de significat cultural a un afecte, a un fenomen que el món exterior té en nosaltres (Arias MaLdonado 2016, 47-53). La importància de tot això és que la investigació neurocientífica moderna atorga a les passions un paper cada cop més important en els processos de pensament (Cortina 20 I I, 106-9). D’alguna manera, són les passions el que ens porta al pensament. És perquè sentim que pensem. El nostre cervell bé podria ser entès com un òrgan que funciona i elabora pensaments en funció de les passions que el món exterior ens fa experimentar, precisament perquè aquestes mateixa passions són el resultat d'impressions i afectes (CoRTINA 20I I, 198-203). Si la manera en què sentim està mediada per les nostres creences, per la cultura en què vivim, i el pensament és fruit d'una resposta a aquestes emocions que l'exterior ens provoca, el pensament és fruit de la cultura en què hem crescut $i$ hem estat educats (Codina Felip 20 I 5, 97-102). Si se socialitza a la gent en contextos democràtics, aquestes mateixes persones mostraran conductes democràtiques, ja que els seus marcs de pensament, la manera en què el seu cervell es configura, els farà tendents a la democràcia (CortinA 20 I I, 116-23). Això pot explicar per què és tan difícil socialment canviar les maneres de govern de les societats, perquè les persones interioritzen les regles polítiques de les societats on viuen.

Socialitzar-se en un context cultural particular és, per tant, determinant per a la manera de pensar, segons mostren les modernes neurociències i d'aquí que s'hagin tret tan importants conclusions per a la política o l'educació (CoRTINA 20II, 217-21). En conseqüència, el poder de domini neoliberal sobre les persones resulta d'un procés educatiu pel qual s'aconsegueix que la gent es comporti d'una manera neoliberal: és perquè han estat socialitzades en un món, en una cultura, neoliberal que actuen com aquest "egoista racional" tan necessari per al capitalisme actual. Les emocions que la gent sent estan intervingudes per components culturals prèviament definits pel sistema neoliberal, de manera que aquest mateix sistema ha configurat les connexions sinàptiques de les persones. Si hi ha un "psicopoder" neoliberal és perquè prèviament $\mathrm{i}$ alhora s'ha desenvolupat una cultura neoliberal que el fa possible. En altres paraules, som neoliberals perquè el món en què vivim ens ha fet així (BaUman 2017, 9-27).

La indústria cultural, l'educació, l'actual sistema de mercat, el bombardeig constant de publicitat a què estem sotmesos és el que configura la nostra estructura cerebral d'una manera tendent a l'establiment d'un comportament d'ho- 
mo oeconomicus (Arias Maldonado 20i6, 197-215). Parlem d'un capitalisme emocional (BAUMAN 2017, 109-55). A través d'una profunda emocionalitat, s'aconsegueix configurar, des del poder del mercat, el nostre cervell. El capitalisme es converteix en una cultura i, d'aquesta manera, s'aconsegueix allò que es busca: que pensem neoliberalment el món i la política, ja que el relat que medià entre les nostres impressions i la interpretació que d'elles fem rau condicionat per eixa mateixa cultura neoliberal (ARIAs MALDONADo 20I6, 197-215). Es crea un "sentit comú" en paraules de Gramsci. Hem acceptat sense adonar-nos, que aquest és el món en què hem de viure. Senzillament no podem pensar d'un altra manera la vida pública perquè la nostra estructura cerebral no ens ho permet. Sotmesos a la constant pressió del capitalisme, de la competència descarnada en tots els àmbits de la vida, a la constant crida a la satisfacció dels nostres impulsos i apetències en el mercat, creador i satisfactor de les mateixes, hem desenvolupat les nostres pròpies cadenes (BAUMAN 20 I7, 27-57).

Amb tot això s'entén que el neoliberalisme lluny d'apostar per una retirada de l'Estat i una absència d'intervenció d'aquest sobre la vida de les persones, en l'òrbita del laissez-faire, el que aquesta ideologia defensa és un tipus molt concret d'intervenció. La intervenció publica per part de l'Estat ha d'anar destinada precisament a crear les condicions propícies per a l'aparició d'aquest prototip humà. Amb aquesta finalitat, la retirada de la iniciativa estatal d'àmbits com la educació, la sanitat o les prestacions socials tindria com a objectiu propiciar un entorn altament competitiu que obligués als individus a procurar-se aquests mateixos serveis en el mercat, emprant els seus recursos privats, fomentant així un pensament fortament economicista de maximització de la satisfacció i disminució dels costos: una actitud empresarial de les persones, que es veurien llançades a una carrera competitiva per fer-se amb les millors oportunitats (LAVAL i DARDOT 20 I 5, 217-25). La constant competició per aquests serveis és el que fa aparèixer la mentalitat d'homo oeconomicus en els subjectes concrets que, a costa de la repetició constant de la mentalitat maximitzadora de beneficis, interioritza aquest comportament, que passa a ser contemplat com allò "normal". Fruit d'aquest procés és que es condicionen les connexions sinàptiques al cervell dels individus, que al remat, es comporten sempre, en tot àmbit de la vida, com a egoistes racionals, perquè és com culturalment entenen que s'han de comportar i reaccionar front al món: com uns empresaris de si mateixos (LAVAL i DARDOT 2015, 332-7), uns calculadors de beneficis individuals.

Aquesta configuració de la mentalitat i el comportament de les persones com a homo oeconomicus, que es val d'estratègies de control i configuració dels pensament dels subjectes, té importants conseqüències a l'hora d'entendre el ressorgiment del discurs populista com a estratègia electoral i la seva efectivitat 
actual, perquè el sistema capitalista és ja incapaç de satisfer a aquest mateix subjecte que el neoliberalisme ha creat per mantenir-lo. Alhora, el tipus de domini que ha fundat el neoliberalisme ha entrat en fallida amb la crisi de l'any 2008 i açò últim té una importància cabdal a l'hora d'entendre el ressorgiment dels discursos populistes i l'actual moment polític que vivim.

\section{LA Fi de L'hegemonia. LA FALLida de LA LEgitimitaT DEL RÈGIM NEOLIBERAL}

Allò que el neoliberalisme busca amb aquest control neuropolític del comportament de les persones i la creació de l'homo oeconomicus no és sols crear unes condicions antropològiques adequades per al sosteniment del sistema capitalista, sinó que també cerca de dotar-lo d'una legitimitat que permeti el manteniment d'aquest mateix sistema de poder. En aquest sentit, el neoliberalisme no és sols una ideologia política que interpreta la realitat en funció d'uns axiomes teòrics particulars sobre com ha de ser el món. És també una teologia política (Villacañas 2020, 75-81) en tant que tracta de justificar un règim polític des d'una perspectiva particular, fonamentada en l'establiment d'un tipus de poder pastoral que converteix el mercat capitalista en un déu, del qual determinades persones, els polítics pertanyents al denominat establishment ${ }^{5}$, economistes ortodoxos o d'altres professions i persones similars, en tot cas, partidaris de la desregulació dels mercats financers globals, serien els seus profetes i representants, com els sacerdots ho són dels déus tradicionals.

El sistema neoliberal es fonamenta sobre una legitimitat que Max Weber qualificaria com de tipus tradicional. Parlem d'un "sistema tradicional de dominació" quan el sobirà obté el seu poder de la mà d'una tradició cultural donada, així els reis del passat ho eren per tradició (Weber 20 i 2, 94-6). Podem trobar el millor exemple de dominació de caràcter tradicional a les societats teològiques, on els sacerdots ostenten el poder perquè són els coneixedors

${ }^{5}$ Amb el terme "establishment" ens referim a aquelles persones i organitzacions que participen $i$ es beneficien del sistema neoliberal creat amb la revolució neocorservadora dels anys 80 i que encara dura. Aquest "establishment" constituiria una classe social formada pels privilegiats per aquest mateix sistema i que tindrien, per tant, una posició de poder sobre aquelles altres persones que no en pertanyerien a aquesta mateixa classe. Aquest "establishment" inclouria a polítics, periodistes, grans financers i empresaris, comandaments policials i caps d'importants organismes internacionals com l'FMI o l'OMC. Serien un grup social tancat, l'accés al qual estaria vedat a tota persona aliena a aquests mateixos cercles de poder, constituint per aquest motiu una veritable "casta" dirigent per a molts intèrprets de la realitat política i social del món contemporani (JONES 20I4, 31-73). Aquesta "casta", aquesta classe dirigent seria el blanc de les critiques de partits populistes, que acusarien a aquestes persones dirigents dels grans mals de les actuals societats, com ara l'increment de les tasses d'atur o la crisi econòmica de l'any 2008. 
dels designis del déu tradicional, els designis del qual interpreten. Aquesta voluntat divina, interpretada pels sacerdots, es converteix en la llei que regirà els destins de les gents que viuen sota el domini sacerdotal (WeBER 20 I 2, 1124). La dominació tradicional es produeix quan el sobirà obté la seva legitimitat per a l'exercici del poder de la mà d'una sèrie de tradicions culturals que, al seu torn, actuen com contrafré d'aquest mateix poder del sobirà (WeBER 20I2, 96-102). Existeixen en les societats tradicionals tot un seguit d'experts que interpreten la tradició, els designis del déu i marquen els límits a l'exercici de poder polític (WEBER 20I2, 94-6). La no obediència als designis d'aquestes divinitats per part del sobirà es traduirà en càstigs per al conjunt de la societat en qüestió (WeBER 2O I 2, 102-9). És la secularització d'aquests plantejaments el que ha donat lloc al modern tipus de dominació neoliberal (OrTiz AreLLANO 2OI 5 ).

En l'actualitat, el lloc de Déu ha estat ocupat pel mercat capitalista: els designis d'aquest s'han tornat llei (Gómez Rincón 20I6). Aquest ha estat el canvi operat pel neoliberalisme a favor del sistema capitalista. El neoliberalisme és només una altra manera possible d'entendre el capitalisme, una manera de legitimar-ne un de més extrem del que fins als anys 80 era acceptat (Ortiz Arellano 20 i 5). L'obra de la revolució neoliberal ha estat la creació d'una cultura pròpia per a aquest sistema econòmic i polític (HARDT i NEGRI 2005, 21-43). L'establiment de la normalitat neuronal neoliberal desemboca finalment no només en la creació d'un prototip humà, sinó de tota una cultura. No és exagerat parlar de l'aparició d'una cultura capitalista, d'una tradició cultural, ja que en l'actualitat totes les nostres relacions socials estan intervingudes per prejudicis, per costums, fortament arrelats en el nostre subconscient, però que són en realitat una creació cultural, en aquest cas, neoliberal (Hardt i Negri 2005, 347-75). Per mitjà de les pràctiques de control neuronal s'han aconseguit fundar tots aquests "costums" que han donat peu a una cultura (Ortiz Arellano 20 I 5). Aquesta cultura, aquesta tradició, situa en el centre de la vida la competència entre interessos subjectius enfrontats (Gómez Rincón 20I6).

En el món occidental modern, la competència és la protagonista de tot l'entramat social: les relacions intersubjectives són d'aquesta naturalesa. Avui es competeix per tot. La propietat privada, s'ha tornat una constant preocupació i una nova divinitat: les constitucions de molts països recullen i protegeixen la seva inviolabilitat, a voltes per sobre de l'interès general de la població. Tot això, i molt més, configura un sistema de creences molt sòlid que apuntala la nova tradició, al centre de la qual se situa allò que engloba totes aquestes pràctiques $\mathrm{i}$ creences: la propietat privada inviolable, la competència descarnada, la recerca constant de la satisfacció personal, tot desem- 
boca inevitablement en el mercat, ja que sense propietat privada o competència no hi ha mercat, però sense mercat tampoc hi ha propietat privada ni competència (HaYeK 20 I o, 25-55). Així és com el neoliberalisme sustenta la legitimitat del mercat capitalista, interpretat com un déu del qual depèn el benestar d'uns subjectes convertits en uns egoistes racionals que sols miren pel seu propi benestar individual, convençuts pels nous profetes i sacerdots neoliberals que sols el capitalisme pot satisfer eixes apetències. $\mathrm{O}$ així era fins l'any 2008, quant tot aquest edifici es va venir avall amb la crisi econòmica causada per la fallida del banc d'inversió nord americà Leman Brothers.

El que va ocórrer amb la crisi de l'any 2008 fou que tot el relat neoliberal va ser enderrocat. La ideologia neoliberal s'havia fonamentat en la satisfacció capitalista de l'homo oeconomicus, un prototip humà creat pel propi sistema neoliberal a partir de la manipulació, per mitjà de la cultura de masses i l'educació, que era convenient per al sistema capitalista. L'edifici depenia del fet que els mercats foren capaços de proporcionar a aquest subjecte allò que desitjava: plaers hedonistes en un curt termini de temps, la qual cosa no sols mantenia l'economia, sinó també tot l'entramat polític de les societats modernes. Del funcionament d'aquesta relació entre l'homo oeconomicus i el capitalisme de mercat desregulat, depenia el sosteniment d'un tipus específic de règim polític que s'havia anat construint des dels anys 80 del segle xx i que permetia unes determinades relacions de poder. Si per alguna cosa el sistema capitalista de lliure mercat deixés de subministrar a l'homo oeconomicus aquesta dosi instantània de plaers que necessitava, tot el sistema cauria -el déu hauria estat desemmascarat, i amb ells els seus sacerdots i profetes: els partits polítics de l'establishment o els experts econòmics, entre d'altres (VillacaÑas 2020, 179-85)—. La situació seria l'equivalent a la d'una societat teocràtica quan una terrible epidèmia sacsa la seva realitat d'una forma inexplicable: déu deixaria de ser déu i tot l'aparell polític seria enderrocat. Això és just el que va ocasionar la crisi de l'any 2008: la fi del regim teològic neoliberal.

La crisi i les seves conseqüències van fer que el món quedés desencantat: de sobte el mercat capitalista no era capaç de proporcionar el benestar que l'homo oeconomicus exigeix, i no sols això: les mesures econòmiques i polítiques aplicades per tal de pal-liar-ne els efectes de la crisi, consistents en severs programes d'ajust econòmic, no feren més que afegir decepció al clima social general. El règim capitalista ja no sols no era capaç de satisfer els desitjos hedonistes de l'egoista racional creat pel neoliberalisme; a més a més, exigia d'aquest un sacrifici en el seu benestar per tal de salvar al propi sistema. Això és una cosa que un prototip antropològic com el de l'homo oeconomicus no pot tolerar, car la seva natura és fonamenta en el gaudi, no en el 
sacrifici, el qual interpreta com una falla en la seva llibertat i la seva dignitat com a subjecte (CASTELLS 2017, 15-29). La conseqüència de tot això fou la posada en qüestió per part de la població, educada en el neoliberalisme com a homo oeconomicus, de tot l'entramat institucional de les societats. La crisi de l'any 2008 ocasionà que els partits tradicionals, formants de l'establishment neoliberal, foren responsabilitzats de l'empitjorament de les condicions de vida d'un subjecte que no és capaç d'admetre tal cosa. Si els "sacerdotsgovernants" ja no eren capaços de satisfer la població, era perquè eren falsos profetes i, per tant, havien de ser substituïts per altres que si pogueren fer això mateix ${ }^{6}$ (CASTELLS 20I7, 35-81).

El que va ocórrer doncs, amb la crisi del 2008, fou que el conjunt de veritats, d'interpretacions de la realitat, canvià com a conseqüència de les circumstancies: el sistema de lliure mercat capitalista no fou capaç de respondre a les demandes d'una ciutadania esdevinguda una massa d'egoistes racionals fruit del treball neoliberal de control neuropolític sobre els individus. Així, el bloc històric va caure com a conseqüència de la pèrdua de l'hegemonia del sistema de creences neoliberal, que havia configurat un règim la legitimitat del qual es fonamentava en una percepció teològica d'un mercat desemmascarat ara com una falsa deïtat. Aquesta pèrdua de l'hegemonia neoliberal a l'hora de dotar d'un significat concret els significants flotants, implicà l'obertura d'un nou escenari polític. La caiguda del poder pastoral neoliberal deixà aleshores a la gent susceptible d'un altre tipus de lideratge polític: és el moment dels cabdills. S'obre així l'escenari per a l'adveniment del que seguint a Mouffe hem denominat "moment populista".

\footnotetext{
${ }^{6}$ Aquesta és la causa de l'aparició dels nous moviments socials, com els Indignats espanyols i tants altres que durant l'any 2011 van prendre força arreu del món. L'aparició d'aquest moviments socials escenificaria eixe descontent social front a les polítiques d'ajust destinades a fer front a la crisi econòmica de l'any 2008 i que privarien de drets a uns ciutadans innocents que, segons el relat d'aquest moviments, pagaven les conseqüències d'una situació que ells no havien provocat. Aquets moviments socials reivindicarien la fi d'eixes polítiques d'ajust amb la finalitat de recuperar els drets que estaven sent arrabassats a la gent, com el dret a una cobertura sanitària universal o una educació publica i de qualitat. Aquesta defensa de drets socials conquerits temps enrere ha fet que estos moviments socials foren catalogats com a conservadors per part d'alguns intèrprets, però més enllà de la classificació ideològica dels mateixos, el que posen de manifest estos moviments és que existeix un fort descontent ciutadà front les classes dirigents, evidenciant que el relat neoliberal sobre la realitat, la legitimitat del sistema, estava trencada. En tal sentit es pot interpretar el lema "se va a acabar la paz social' que no poques vegades s'escoltava en les places ocupades pel moviment dels Indignats, perquè amb la caiguda de la legitimitat del règim, i la no satisfacció de l'homo oeconomicus era impossible mantenir la societat en un estat de calma, com fins aleshores havia sigut possible gracies a la satisfacció dels desitjos d'eixe prototip humà: quant les seves demandes no són satisfetes, l'egoista racional, es revela contra el sistema i busca la seva satisfacció per altres vies, com pot ser, en aquest cas, el vot a formacions anti sistema que empren del discurs populista (CASTELLS 2017, 84-6).
} 


\section{El RESSORGIMENT DEL DisCURSOS POPUlisteS}

Quan parlem de "discurs populista" cal especificar a què ens estem referint. En l'actualitat més immediata, el propi terme "populista" ha esdevingut un d'aquells significants buits que és significat i resignificat en funció de les conveniències electorals de les diferents forces polítiques en lluita per ostentar l'hegemonia. La qualificació de l'adversari polític com a "populista" s'ha convertit en habitual en els temps que corren, de tal mode que avui qualsevol discurs de qualsevol força política és susceptible de ser inclòs en la llista de "discursos populistes" amb la finalitat de desacreditar a tal força política i el seu programa electoral de cara a la ciutadania. Això és propi del moment de fi de bloc històric en què vivim immersos: amb l'hegemonia política del neoliberalisme perduda s'ha creat un buit de legitimitat del règim, un buit que cal omplir per tal de construir un nou bloc històric o refer-ne l'anterior. Així s'ha obert la disputa per l'hegemonia i en aquest context la lluita entre els diferents partits, representants de diferents ideologies. És en aquest context on el discurs populista resulta útil.

Amb populisme s'allludeix a un tipus molt concret d'estratègia política de conquesta del poder. No és una ideologia com a tal, per això existeixen populismes d'esquerres i de dretes. Més aviat el populisme és un tipus de discurs pel qual una força política determinada, amb una ideologia concreta (socialista, liberal, republicana, etc.) intenta, en un context democràtic, definir l'escenari electoral d'una forma favorable als seus interessos polítics.

El populismo no es en realidad una ideología política; se trata más bien de una "lógica de acción política". Más importante que los contenidos doctrinales son aquí las formulas o los estilos de los que hacen uso, la retórica empleada, y la manera en la que aspiran a hacerse con la hegemonía. Por eso puede hablarse de un populismo de izquierdas y de otro de derechas. Si los contenidos ideológicos jugaran un papel central esta distinción no sería posible, o lo será al precio de perder precisión semántica (VAlLESPín i Bascuñán 2017, 55)

Tal cosa s'aconsegueix per mitjà de l'apropiació dels significants buits, definint-los a conveniència de la força política que empra del discurs populista. Per això mateix aquest tipus d'estratègia, el populisme, sols és efectiva en moments de crisi de règim com la que vivim, ja que és en moments així on aquests significants buits han perdut el seu significat específic, fruit de la pèrdua d'hegemonia de la força dominant (Errejón i Mouffe 2016, 56-61): si abans de l'any 2008 l'hegemonia cultural neoliberal feia entendre la "llibertat" com una situació d'absència de coacció de l'individu, la pèrdua d'aquesta hegemonia del 
neoliberalisme arran de la crisi del 2008 ha fet que el significant buit llibertat pugui ser resignificat a conveniència de qualsevol altra ideologia. Així doncs, per mitjà del discurs populista, una força política diferent ideològicament dels partidaris del neoliberalisme pot establir que "llibertat" significa una situació on l'individu no és sotmès a dominació per part d'altres persones o de les circumstancies que l'envolten (VALLeSPín i Bascuñán 20I7, 89-104).

Aleshores podem dir que el discurs populista no és una ideologia, sinó una eina de conquesta de l'hegemonia a disposició de qualsevol força política (Biglieri 2020). Però, per què el discurs populista és una eina de conquesta d'hegemonia tan efectiva en l'actual context social? Si entenem el populisme com un discurs, tal i com ho estem fent, que és emprat amb indiferència des de qualsevol perspectiva ideològica, tant per Donald Trump com per Unidas Podemos, podem veure que ambdues formacions, tot i ser ideològicament contraries, mantenen en els seus discursos electorals un llenguatge similar. Podem, doncs, afirmar que el discurs populista té una sèrie de característiques que el fan únic i també molt efectiu a l'hora d'aconseguir allò que es pretén en emprar-lo en l'actual context polític marcat per la crisi de legitimitat del sistema neoliberal.

En términos generales, responden [els discursos populistes] a procesos de brusco cambio social frente a los que se reacciona invocando la necesidad perentoria de revertir la situación creada por dichas transformaciones, una de cuyas consecuencias principales es la "pérdida de la comunidad" y la distorsión del sistema de mediación política. Dicha reacción se expresa mediante la descripción con tintes dramáticos del momento en que nos encontramos. Su estilo comunicativo se impregna de negatividad, de indignación y de un espíritu cuasi-trágico respecto al estado del país en cuestión, que clama por la restauración de un orden - de convivencia, cultural, político- que se entiende subvertido (VAllespín i BasCUÑÁN 20I 7, 55)

En primer lloc, el populisme és caracteritza per ser un discurs que empra una estratègia divisòria de la societat consistent en la classificació de la ciutadania en dos grups enfrontats: el "nosaltres" i els "altres". El "nosaltres" al qual el discurs populista apel.la és definit com el "poble", o la "majoria social" que jau oprimida per un "altre", un enemic, causant d'aquesta situació d'opressió que pateix el poble (VALLESPín i BASCUŃÁn 20I7, 68-75). Ambdós termes, "poble" i "altre" o "enemic" són significants buits, per això aquestes categories prenen formes diferents segons la ideologia del partit polític que empra del discurs populista. El "nosaltres" pot ser tant el poble oprimit per unes suposades elits polítiques o financeres, esdevingudes un enemic — tal com l'empren els popu- 
listes d'esquerra-, com pot ser un conjunt de persones que pateixen a causa d'estrangers i d'immigrants que els lleven la feina —segons l'argumentació dels populistes de dreta (Del Búfalo 20I4) - L La dicotomia "poble"/"enemic" del populisme es fonamenta en una visió de la política basada en la concepció de Carl Schmitt, segons la qual la política és una lluita per la supervivència del poble front a un enemic. Aquesta característica té una gran transcendència en el context actual, per aconseguir que aquella força política que l'empra es faci amb el poder polític (Gómez Rincón 20I8) però no és l'única.

El discurs populista també és caracteritza per un marcat recurs a l'híperlideratge d'un líder carismàtic que es converteix en el representant d'una enorme massa de persones: el "poble" construït pel propi discurs populista (Gómez Rincón 20I9). El líder populista aglutina a tot un conjunt de persones amb diferents interessos, molt sovint enfrontats, però que gracies al líder són capaços de conviure. El líder populista, que representa al "poble", no és vist com un polític més sinó com un membre més d'aquesta part oprimida de la societat, perquè en forma part, amb independència que pertanyi a una classe social diferent a la de la majoria dels seus votants (Villacañas 20 i 5, 75-81). El líder és la encarnació del "poble" i és converteix per això mateix en cabdill d'aquesta mateixa entitat construïda retòricament. El que s'aconsegueix amb el discurs populista és que una enorme quantitat de persones s'identifiqui emocionalment amb la figura del líder del partit, de manera que el que conta ja no és el partit sinó aquest mateix cap visible que aconsegueix, per mitjà del seu carisma, construir una gran base social que li doni suport electoral (VALLESPíN i BASCUÑ́n 20 I7, 79-83).

En tercer lloc, el discurs populista és reconeix per la seva constant apellació a les emocions de l'electorat i no tant a la raó del subjecte individual. El que pretenen aquells partits que empren del discurs populista és el recolzament emocional de l'electorat a la qual cosa obeeixen les altres dues característiques descrites. Així, tant el recurs a la dicotomia amic/enemic com l'híperlideratge tenen com a funció aconseguir una identificació emocional del subjecte amb el partit, deixant de banda tot recurs a la raó (Gómez Rincón 20I9). El populisme, doncs, prioritza les emocions, com la de la pertinença a un grup: el del nosaltres, el poble, unit sota un líder victoriós que ens representa o la por front a un enemic que presenta una amenaça a la nostra supervivència, als nostres interessos com a "poble" format per individus.

Aquestes tres característiques són les que fan que el discurs populista sigui tan efectiu avui, perquè troben en l'homo oeconomicus creat pel neoliberalisme al subjecte ideal per rebre el missatge i, per tant, poder disputar l'hegemonia als partits d'un establishment qüestionat arran de les conseqüències de la crisi del 2008. El populisme tracta d'aprofitar les circumstàncies que crea el món mo- 
dern, de la mateixa manera que fa qualsevol marca comercial amb la publicitat: generar impulsos de compra en base a emocions (BAUMAN 2017, 109-55). El discurs populista és per això necessàriament emocional, perquè el que busca és mobilitzar els impulsos de l'electorat per a la "compra" d'un producte polític determinat: el partit populista (VALLESPín i BASCUÑ́n 20I7, 104-17). I és ací on entren en joc la dicotomia amic/enemic i l'híperlideratge a què ens hem referit.

La "lluita" entre un poble que sofreix a conseqüència de les injustícies causades per un "altre", enemic d'aquell poble, té la funció de crear en l'electorat un sentiment de temor que impulsi a un individu que sols pensa en ell mateix a defensar-se front una agressió figurada, creada retòricament pel líder populista. Aquest tipus de discurs té una gran eficàcia entre l'egoista racional modern perquè dona a aquest subjecte allò que vol: una explicació simple d'una realitat complexa que permet descarregar les ires contra un grup de persones concret, el de l'enemic (Vallespín i Bascuñán 20I7, 104-8). El líder populista pot prometre als seus oients una completa satisfacció dels seus desitjos, encara que aquests siguin irrealitzables en la pràctica o totalment contraprudents per als interessos de la societat en el seu conjunt. Així un líder populista pot argumentar que la causa de la crisi de l'Estat del benestar és que els immigrants viuen a costa dels subsidis públics, esgotant els recursos econòmics de l'Estat; de manera que l'immigrant és convertit en un "enemic" que amenaça al "poble" format pels ciutadans nadius que veuen com els seus drets socials es veuen retallats. El líder populista proposarà l'expulsió dels immigrants del país amb la finalitat de protegir aquests interessos dels nadius, o la construcció d'un mur que impedeixi l'entrada dels estrangers. Promeses que tot i que són irrealitzables donen a l'homo oeconomicus neoliberal allò que vol: una satisfacció instantània dels seus desitjos i apetències (Gómez Rincón 2018).

En altres paraules: l'auge del populisme actual és el resultat d'hàbils campanyes destinades a aprofitar en benefici propi dels partits polítics que l'empren les condicions socials que el sistema governamental neoliberal ha creat i que fruit de la crisi econòmica de l'any 2008 és incapaç d'afrontar. Aquests partits recorren al discurs populista per trencar el monopoli dels partits tradicionals a l'hora d'establir el significat dels significants buits (López ALós 20I7) i aquells mateixos partits de l'establishment buscaran amb el discurs populista reconquerir aquesta hegemonia perduda. ${ }^{7}$ No obstant això, el populisme és només això, una estratègia electoral, un discurs destinat a la captació de vots que funciona

${ }^{7}$ En l'actual moment populista no sols els partits "anti sistema" recorrerien a aquets tipus de discurs. Els partits de l'anomenat establishment també ho estarien fent. La construcció de la dicotomia entre partits d'ordre o constitucionals front a partits populistes o anti sistema, respondria a una lògica populista de construcció d'un enemic que amenaça el "poble" i la seva seguretat. En aquest cas, l'enemic serien eixos partits qualificats com anti sistema o populistes, front als representats de les gents d'ordre temoroses de perdre el seu patrimoni o la seva seguretat individual 
per la seva capacitat de sintonitzar amb el clima social imperant, sent capaç de construir un relat alternatiu que funciona com a argument de vendes per a un producte polític alternatiu a l’oferta existent al mercat (Gómez Rincón 2019).

El relat populista té la capacitat d'emocionar l'electorat, creant expectatives i il.lusions, de la mateixa manera que fan les marques a través de la publicitat (VillacaÑas 2015, 39-49). És aquest discurs electoral, que opera subvertint les condicions de dominació neoliberal, el que permet als nous partits arrabassar l'hegemonia als seus contrincants, els partits tradicionals, perquè la pèrdua de credibilitat del sistema neoliberal ha propiciat que els "significants buits" com són el de "poble", "sistema" o "democràcia" puguin tornar a ser definits. L'hegemonia torna a estar en joc, ja que el poder cultural neoliberal sobre la vida s'ha quedat obsolet, fruit de la incapacitat del sistema de lliure mercat per satisfer a l'homo oeconomicus i, per tant, la cultura política actual viu un moment d'efervescència, fruit de la lluita per aquesta resignificació dels significants buits per tal de conquerir una hegemonia cultural que doni una victòria electoral a un partit sobre els altres competidors en el marc d'un sistema democràtic molt competitiu.

Amb tot això es pot afirmar que la principal causa que en l'actualitat estiguem assistint a un moment polític marcat per l'agressivitat és que vivim un "moment populista", on les diferents forces polítiques, amb visions ideològiques enfrontades sobre com ha de ser la societat i el món en el seu conjunt, lluiten per tal d'ocupar una hegemonia cultural que ha quedat vacant fruit de la caiguda del relat neoliberal. Les forces polítiques en qüestió empren les esmentades tècniques populistes perquè aquest discurs és el que millor els permet aprofitar al seu favor les actuals condicions del món, creades per anys d'hegemonia cultural neoliberal, que han donat lloc a un homo oeconomicus obsessionat amb la pròpia satisfacció dels seus desitjos particulars, el qual després de la caiguda del relat neoliberal en el descrèdit i la crisi del 2008 ha quedat orfe de representació i vulnerable front a aquests discursos i les seves promeses demagògiques. Avui vivim un moment populista precisament perquè el relat que donava sentit al món fou destruït per la crisi de l'any 2008 i això ha permès que sigui possible tornar a disputar aquesta mateixa hegemonia cultural des del terreny de la política electoral.

front aquells altres partidaris d'okupes o d'amnistiar delinqüents. Veiem un recurs emocional a una por infundada a un enemic que s'ha construït de forma retòrica en aquests discursos. Un enemic que sols pot ser derrotat per un líder carismàtic: el del partit. Així, els partits defensors de l'establishment no serien aliens al discurs populista, com l'exemple d'Emmanuel Macron posa de manifest. Així, es confirma que el populisme no és una ideologia tancada, com el socialisme o el liberalisme, sinó una estratègia electoral que qualsevol força política pot emprar a conveniència (VAllespín i Bascuñán 2017, 189-93). 


\section{Conclusions}

Vivim, per tant, un moment populista en l'actualitat perquè s'ha trencat el monopoli ideològic del neoliberalisme - una cultura política vigent des dels anys 80 del segle $\mathrm{xx}$ - a conseqüència d'una crisi econòmica. Tot un relat sobre el món que dotava de legitimitat a un règim polític i social molt determinat ha entrat en fallida i, com a resultat d'això, tot un seguit de relats ideològics alternatius poden ara fer-se amb el lloc hegemònic perdut per les forces d'un establishment en hores baixes i mancades de legitimitat per la seva incapacitat d'acontentar al mateix prototip humà que fins aleshores els permetia mantenir el seu poder. Aquesta crisi de règim, que conviu amb la pervivència del subjecte creat pel neoliberalisme, és el que fa efectiu el discurs populista perquè les diferents forces polítiques lliuren la batalla per ocupar una hegemonia cultural vacant des dels esdeveniments que van tenir lloc de l'any 2008 endavant. Aquest és, doncs, un nou temps polític caracteritzat per l'enduriment de la lluita electoral, precisament perquè el que està en joc ara és el poder de construir un nou bloc històric un nou relat hegemònic i en conseqüència un nou món, completament diferent al conegut fins ara.

Amb tot això, és possible que al final d'aquest procés de lluita per l'hegemonia cultural, del moment populista que vivim, un altra manera d'entendre el món, un altra visió ideològica, es faci amb el lloc de monopoli cultural que fins ara ostentava el neoliberalisme: el lloc des del qual poder definir com s'ha d'entendre la realitat i, per això mateix, des del qual poder canviar-la per un altra de més justa per a tothom o, per contra, d'una forma molt més injusta i egoista de gestionar els assumptes polítics en un món fortament globalitzat.

La vacant deixada pel neoliberalisme com a ideologia dominant - la seva pèrdua de l'hegemonia- ha donat lloc a l'actual moment populista on les diferents forces lluiten per la conquesta d'aquesta hegemonia. És per això que ara totes les forces polítiques empren del discurs populista en certa mesura, però no totes defensen el mateix. Per això, ara més que mai, és necessari estar en guàrdia i promoure un pensament polític crític, perquè pel moment populista que estem vivint és possible que forces polítiques contràries als drets socials de les minories o dels oprimits, conquerits fa relativament poc de temps, troben els suficients seguidors com per establir una hegemonia cultural que retalli i elimini aquests drets. Els ciutadans tenim, doncs, molt més poder que mai per construir el món del futur i això implica una major carrega de responsabilitat política en les nostres decisions. La pregunta és: està la societat post-neoliberal en condicions d'aprofitar l'oportunitat que el moment populista obre per millorar les expectatives de futur de les pròximes generacions? 


\section{BIBLIOGRAFIA}

Anderson, P. 2017, Las antinomias de Antonio Gramsci, Madrid: Akal.

Arias Maldonado, M. 20 i6, La democracia sentimental. Política y emociones en el siglo XXI, Barcelona: Página Indómita.

Bauman, Z. 20I7, Vida líquida, Barcelona: Editorial austral.

Biglieri, P. 2020, "Populismo ¿izquierdas y derechas?”, Recerca. Revista de pensament $i$ anàlisi, 25: 5-24.

Cadahia, M. L.; Coronel, V.; Guanche, J. i Stoessel, S. 2020, "Hacia una lógica del populismo: de la ruptura de las instituciones a la institucionalidad populista", Recerca. Revista de pensament $i$ anàlisi, 25: 25-46.

Cano, G. 20I 5, Fuerzas de flaqueza. Nuevas gramáticas politicas, Madrid: Los libros de la catarata.

Castells, M. 2017, Ruptura. La crisis de la democracia liberal, Madrid: Alianza Editorial.

Cerruti, P. 20I7, "De la biopolítica a la psicopolítica: comunicación, poder y subjetividad a partir de Michael Foucault", Astrolabio, 19: 144-203.

Codina Felip, M. J. 20 i 5 , Neuroeducación en virtudes cordiales. Cómo reconciliar lo que decimos con lo que hacemos, Barcelona: Ediciones octaedro.

Conill, J. I99I, El enigma del animal fantástico, Madrid: Tecnos.

Cortina, A. I990, Ética sin moral, Madrid: Tecnos.

Cortina, A. 20 i i, Neuroética y neuropolitica. Sugerencias para la educación moral, Madrid: Tecnos.

Cruz Ortiz de Landázuri, M. 2017, "De la biopolítica a la psicopolítica en el pensamiento social de Byung- Chul Han”, Athenea Digital, 17 (1): 187-203.

Del Búfalo, E. 20 I 4, "El pueblo vacío del populismo. Una crítica desde la multitud democrática”, Pasajes. Revista de pensamiento contemporáneo, 46: 62-74.

Errejón, I. i Mouffe, Ch. 20i6, Construir pueblo. Hegemonía y radicalización de la democracia, Barcelona: Icaria.

Fernández Agís, D. 2009, “¿Qué es la biopolítica?”, Cuadernos del Ateneo, 26: 93-8.

Foucault, M. 2009, Nacimiento de la biopolitica. Curso del Collège de France (1978-1979), Madrid: Akal.

Gómez Rincón, J. F. 20 I 8, "La democràcia que agonitza. La difícil relació entre virtut cívica i discurs populista", Interessos filosòfics del present. Actes del XXII Congrés Valencià de Filosofia, València: SFPV, 289-305.

Gómez Rincón, J. F. 20I9, “'Nosotros o el caos’. La relación entre populismo y democracia elitista”, González-Esteban, E., Siurarana, J. C., LópezGonzález, J. L. i García-Granero, M. (ed.), Ética y democracia desde la razón cordial, Granada: Comares, 315-23. 
Gramsci, A. I998, Cartas desde la cárcel, Buenos Aires: Nueva Visión.

Gramsci, A. 20i6, Para la reforma moral e intelectual, Madrid: Catarata.

Gramsci, A. 2017, Escritos (Antología), Madrid: Alianza Editorial.

Han, B. H. 20 I 4, Psicopolitica. Neoliberalismo y nuevas técnicas de poder, Barcelona: Herder.

Hardt, M. i Negri, A. 2005, Imperio, Barcelona: Paidós.

HaYeK, F. I 998, Los fundamentos de la libertad, Madrid: Unión Editorial.

Hayek, F. 20 Io, Principios de un orden social liberal, Madrid: Unión Editorial.

Jones, O. 20I4, El establishment. La casta al desnudo, Barcelona: Booket.

Kunn, TH. 2004, La estructura de las revoluciones cientificas, Mèxic D.F.: Fondo de Cultura Económica.

Laclau, E. 2008, La razón populista, Mèxic D.F.: Fondo de Cultura Económica.

Laclau, E. i Mouffe, CH. 2015, Hegemonia y estrategia socialista. Hacia una radicalización de la democracia, Madrid: Siglo XXI.

Laval, Ch. i Dardot, P. 20 I 5, La nueva razón del mundo. Ensayo sobre la sociedad neoliberal, Barcelona: Gedisa.

Lemm, V. (ed.) 201о, Michael Foucault: neoliberalismo y biopolitica, Santiago de Chile: Editorial de la Universidad Diego Portales.

López Alós, J. 2017, “El debate sobre el populismo en España (2014-2017). Un estado de la cuestión", Pensamiento al margen. Revista digital, 7: 146-77.

Ortega y Gasset, J. 2007, Ideas y creencias, Madrid: Alianza Editorial.

Ortiz Arellano, E. 20 I 5, "Biopolítica y neoliberalismo: biopoder totalizante", Xihmai, 19 (10): 1-22.

Schmitt, C. 2014, El concepto de lo político, Madrid: Alianza Editorial.

Serrano Marín, V. 20 I7, El orden biopolítico, Barcelona: El Viejo Topo.

Stenger, M. B. i Roy, R. K. 20 I I, Neoliberalismo. Una breve introducción, Madrid: Alianza Editorial.

Vallespín, F. i Bascuñán, M. M. 2017, Populismos, Madrid: Alianza Editorial.

Vergara Estévez, J. 2009, "La concepción del hombre de Friedrich Hayek", Revista de filosofía, 65: 161-76.

Villacañas, J. L. 20 i 5 , Populismo, Madrid: La huerta grande.

Villacañas, J. L. 2020, Neoliberalismo como teología politica. Habermas, Foucault,

Dardot, Laval y la historia del capitalismo contemporáneo, Ulzama (Navarra): Ned ediciones.

Weber, M. 2012, Sociología del poder. Los tipos de dominación, Madrid: Alianza Editorial. 